\title{
Adopting an Ecosystem Services-Based Approach for Flood Resilient Strategies: The Case of Rocinha Favela (Brazil)
}

\author{
Silvia Ronchi *(-) and Andrea Arcidiacono \\ Department of Architecture and Urban Studies, Politecnico di Milano, via Bonardi 3, 20133 Milano, Italy; \\ andrea.arcidiacono@polimi.it \\ * Correspondence: silvia.ronchi@polimi.it
}

Received: 29 October 2018; Accepted: 18 December 2018; Published: 20 December 2018

\begin{abstract}
Rocinha (Rio de Janeiro, Brazil) is the largest favela in South America. It is located on a steep mountain slope in the Tijuca National Park with a population of over 160,000 living in poor environmental, health and hygiene conditions. The geomorphological and urban setting of Rocinha makes it vulnerable to natural hazards, with the greatest risk posed by flooding or landslides, compromising the precarious balance between ecosystem services (ES) provision and human well-being. The paper aims to assess and map ES provision in a context where available data to identify areas vulnerable to natural risks is limited. The ES analyses were adapted to the specific socio-economic and environmental context of favelas, which are characterised by dense, continuously built-up environment and a high proportion of impervious surfaces, leading to deteriorating environmental, health and hygiene conditions over time. The ES-based approach was pivotal for setting out strategies—including nature-based solutions (NBS) - to mitigate disaster risk and increase local resilience. These strategies were selected taking into account the context of Rocinha and feasibility. The research shows that ES assessment can be the starting point for projects based on NBS with a view to increasing resilience even in environmentally critical contexts.
\end{abstract}

Keywords: ecosystem services; nature-based solutions; flood resilience strategies; Rocinha favela; mapping; water upstream

\section{Introduction}

Floods and landslides now pose the most frequent risk of damage to urban communities and natural environments. To mitigate against the destructive force of natural disasters and reduce the vulnerability of local populations, environmental management strategies such as nature-based solutions (NBS) are increasingly applied for mitigation and prevention [1].

The overexploitation of natural resources in a context like Rocinha (the largest favela in South America with a population of over 160,000 living in just 0.8 square kilometres of steep, rugged terrain) increases the pressure on the ecosystem and, consequently, aggravates disaster risk because the protective functions of the ecosystem against natural hazards fail as they deteriorate or are destroyed [1].

The result of rapid urbanisation and expansion, Rocinha is slowly creeping up the surrounding hillsides and destroying forests, which increasingly exposes it to natural hazards such as floods and landslides.

Geodynamic, hydro-meteorological and climate events mean that the risk from extreme water events is increasing, as is the number of people affected by them. As Assis Dias et al. note, between 1991 and 2010, Brazil recorded almost 39,000 natural disasters caused by droughts, floods, windstorms, 
landslides, tornados, hail, and frost [2]. These disasters destroyed many buildings, causing displacements and deaths [3]. The most serious events were the 2001 floods which caused the country's worst ever natural disaster in its mountainous region, and the 2010 landslides which caused over 40 fatalities among the inhabitants of a Rio de Janeiro shantytown after a rainstorm [1,4].

Nature-based solutions can increase the provision of urban ecosystem services. Solutions of this kind include green spaces (such as urban parks, gardens, forests, vacant lots and orchards) and so-called "blue infrastructure" (such as streams, lakes, water retention ponds and water springs). Ecosystem services can be defined as "the benefits that humans obtain from ecosystem functions" $[5,6]$, or as the "direct and indirect contributions from ecosystems to human well-being" [7] that make human life possible in natural ecosystems.

One of the services provided by urban ecosystems is their contribution to the water regulation cycle as rainfall capture by vegetation and permeable soils reduces the pressure on urban drainage systems and minimises the risk of flooding. Water drainage is even more critical in a context such as Rocinha, where buildings occupy 695,000 square metres, or $80 \%$ of the total area of 850,000 square metres.

Adopting an ES framework can help to establish appropriate management, conservation, and renewal strategies by establishing which areas are most exposed to risk from natural disasters and the appropriate NBS for restoring them [8-10].

Rainfall-runoff monitoring and upstream water yield forecasting modelling are essential technical processes for disaster risk management. Their assessment and mapping are ES-based approaches that aim to reduce a community's vulnerability and increase its resilience to natural hazards [1,11]. Making them "resilient" entails maintaining, creating or restoring conditions that will sustain ES provision, which requires an understanding of complex, highly variable environmental dynamics.

Resilience-focused ES provision can be achieved by implementing several nature-based solutions, which have been defined as "living solutions inspired and supported by the use of natural processes and structures, and are designed to address various environmental challenges in an efficient and adaptable manner, while simultaneously providing economic, social, and environmental benefits" [12]. Nature-based solutions use ecosystem-based approaches, biomimicry, or direct use of elements of biodiversity [13] such as natural elements and processes in urban areas, landscapes and seascapes [14]. Within this methodological framework, nature-based solutions implement an ES-based approach, addressing ecological, social and economic challenges by making use of natural processes and ecosystem services for functional purposes. Specifically, they can mitigate flooding, droughts, erosion and landslides [15].

Despite growing interest in ES-based approaches, the application of this concept to water resource management has been hindered by a lack of practical definitions and methodologies [16]. This study uses a water yield model to assess the condition of ecosystem services and suggests potential nature-based solutions to water regulation as a way of mitigating and preventing the risk of flooding and landslides.

The article adopts an ES-based approach, overcoming the problems of the lack of data on Rocinha for mapping and assessing water regulation. Another peculiar aspect of the favelas, the high percentage of land covered by artificial surfaces and their poor environmental quality, has also limited ES assessment. We tested a variety of ES assessment methods in order to show how ES frameworks can use nature-based solutions to develop strategies with a view to increasing flood resilience.

The article is structured as follows. Chapter Two describes the data, materials and methods used. Chapter Three illustrates the main findings, while Chapter Four discusses them and also outlines some potential directions for future research. Chapter Five provides some conclusions.

\section{Materials and Methods}

The city of Rio de Janeiro has an estimated population of 6.3 million living in an administrative unit of $1255.3 \mathrm{~km}^{2}$ [17]. In recent decades, the city has experienced rapid expansion, attracting over 
1.4 million urban poor people to its favelas [18], which are characterised by slum conditions, extremely high population density (5261.12 inhabitants $/ \mathrm{km}^{2}$ ) and a lack of green areas and public amenities, although they have generally retained a strong sense of social identity and "sense of belonging" $[19,20]$.

Rocinha is the largest favela in South America, with a population of over 160,000 [21]. It lies in a steep, rugged landscape of just 0.8 square kilometres. Its dense, continuous built-up environment and high proportion of impervious surfaces is the result of rapid, unplanned development [21], leading to deteriorating environmental, health and hygiene conditions over time.

As Arcidiacono et al. note, the social and physical conditions of Rocinha resemble those of a formal city [21]. However, it is beset by a large number of critical, complex ecological and environmental issues. These include a patchy, incomplete sewage system (the absence of purification plants means that the water supply is often polluted) and high-density, unsafe buildings the construction of which has neglected any considerations of density, light, aeration or any of the principles associated with twentieth-century urban planning. Environmental degradation has compromised the provision of urban ecosystem services, radically modifying the ecological equilibrium of Rocinha and the Rio de Janeiro region. The area is impacted by deteriorating ecological conditions caused by the loss of natural green spaces, alteration of the water cycle with patchy or absent purification, soil erosion and the urban heat island effect [21].

Rocinha is located on a steep mountain slope in the Tijuca National Park [22] and occupies less than a square mile of land. Its geomorphological situation has influenced its urban development: lack of space for expansion has altered construction patterns, leading houses to be built on top of one another and making the provision of green space between blocks problematic (Figure 1). ES provision for Rocinha is influenced by and dependent on the surrounding area: to the north lies a very steep hill of woods and shrubs with a high habitat quality overlooking the city of Rio de Janeiro, while to the south lies the nearby coastal zone, whose beaches, ocean and estuaries provide several ecosystem services.

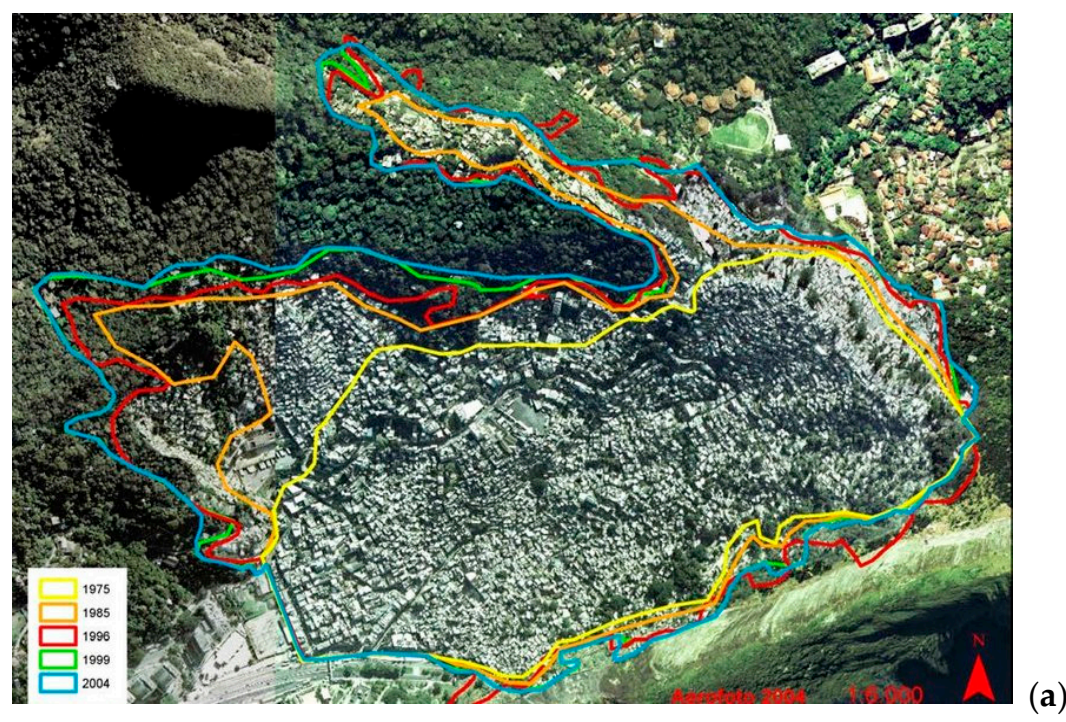

Figure 1. Cont. 


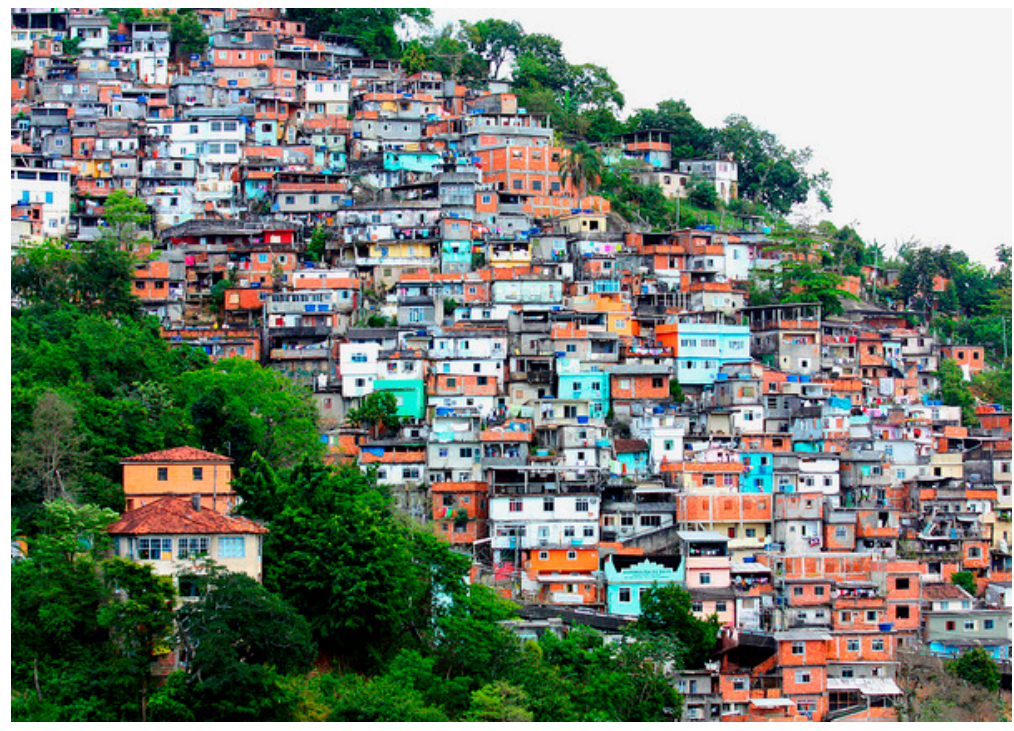

(b)

Figure 1. (a) Growth of Rocinha between 1975 and 2004 [1]; (b) Rocinha Buildings. Source: http: / / reversehomesickness.com/south-america/favelas-rio-de-janeiro/.

The result of rapid urbanisation and expansion, Rocinha is slowly creeping up the surrounding hills and destroying forests, which increasingly exposes it to natural hazards such floods and landslides. Geodynamic, hydro-meteorological and climate events mean that the risk from extreme water events is increasing, as is the number of people affected by them. As Assis Dias et al. note, between 1991 and 2010, Brazil recorded almost 39,000 natural disasters caused by droughts, floods, windstorms, landslides, tornados, hail, and frost [2]. These disasters destroyed many buildings, causing displacements and deaths [3]. Major flood events occurred in 2001 with the worst natural disaster in the mountainous region and in 2010 when landslides struck a Rio de Janeiro shantytown after a heavy rainstorm, causing more than 40 fatalities [1,4].

As previously mentioned, dealing with resilience requires an understanding of the conditions/status, trends and complex dynamics of ES. An ES-based approach can strengthen the resilience of communities and their natural resources.

ES assessment was based on three different services: habitat quality, carbon sequestration and nutrient retention. The assessment of the first two services is not detailed in this paper. Instead, we focus on nutrient retention, and estimate the contribution of vegetation and soil to water purification in removing pollutants from run-off as one of the main regulating services. Besides the final output, the nutrient retention model delivered several key intermediate results that can help understand how the different data of the model interact with each other and how they affect the final output. One of these results provided by the model is a map of upstream processes which shows how flooding is influenced by morphological conditions and hydrological dynamics.

The assessment was conducted using InVEST (Integrated Valuation of Ecosystem Services and Tradeoffs) software, freely downloadable from the website of the Natural Capital Project and jointly developed by Stanford University, the University of Minnesota, the Nature Conservancy and the World Wildlife Fund (WWF). InVEST is an ES-based geographical, economic and ecological accounting tool for regional and urban planning in terms of restoring and conserving the soil's natural capacity to provide ecosystem services [23].

The model assigns to each Land Use/Land Cover (LULC) class information on soil quality (e.g., pedogenetic characteristics by Land Capability Classification), vegetation characteristics (e.g., vegetation canopy) and additional climate data and geomorphological information.

The output of ES assessment is highly dependent on the inputs, such as spatial resolution and data quality, which depend on the individual ES. For example, different studies have highlighted how 
the Digital Elevation Model (DEM) affects the delivery of nutrients along hill slopes and, therefore, the output [24].

Data collection for Rocinha was one of the most demanding stages of the research, as available data are generally not sufficiently detailed (being typically scaled for the metropolitan area of Rio de Janeiro), and direct acquisition is not recommended for safety reasons. The involvement of local civil society organisations (Il Sorriso dei miei Bimbi, an Italian social programme founded in 2002 to improve socio-educational conditions in Rocinha), research institutions (Universidade Federal do Rio de Janeiro) and state departments helped to fill gaps in our information. The remaining missing data were estimated or adapted from the scientific literature. The university provided important data for the creation of the DEM using the most appropriate web sources to derive the necessary input data (i.e., LULC, geomorphological and climate data). The Il Sorriso dei miei Bimbi programme helped verify the data acquired from web sources (e.g., LULC, presence of green spaces, information on buildings).

As required by InVEST software, the nutrient retention model—in this case used to estimate the upstream process-requires various kinds of input data, which are listed below.

1. A DEM specifically designed for this research, considering the isolines provided by Universidade Federal do Rio de Janeiro (only for the Rocinha area), the DEM developed by the United States Geological Survey (https://earthexplorer.usgs.gov/), and geological and geomorphological data provided by the Instituto Brasileiro de Geografia e Estatística (http:/ / downloads.ibge.gov. br/downloads_geociencias.htm). Given the complexity of interpolation processing for DEM generation and a lack of detailed data, mapping did not extend to the entire metropolitan area of Rio de Janeiro but instead focused on Rocinha, while including the surrounding area with significant slopes and changes of elevation. DEM resolution was set at $5 \times 5 \mathrm{~m}$ cells, within the range of between 4 and $10 \mathrm{~m}$ suggested by Salata et al. as the optimal resolution for model performance [24].

2. The depth of root-restricting layers to estimate the amount of soil that is amenable to root plants in view of their significant flood mitigation capacity. These data were derived from information on soil textures in the "Mapa de solos do estado do Rio de Janeiro" available on the EMBRAPA website of the Ministry of Agriculture, Livestock and Food Supply (https: //www.embrapa.br/) and data published by the Brazilian Institute of Geography and Statistics (https:/ / www.ibge.gov.br/). Information on the root-restricting layer depth was also estimated using theoretical data $[25,26]$.

3. Data on average annual precipitation for each cell, collected from the Brazilian Institute of Geography and Statistics (available at https:/ /www.ibge.gov.br/).

4. Plant-available water content (PAWC) as an indicator of the ability of soil to retain water and make it sufficiently available for use by plants. It strongly affects the runoff process, given that plants typically respond to flooding by rooting [27]. As suggested by the InVEST User's Guide, PAWC was calculated using SPAW (Soil-Plant-Air-Water) software developed by the National Agricultural Library of the United States Department of Agriculture (Washington, DC, USA) in cooperation with the Washington State University (http:/ / hydrolab.arsusda.gov/ SPAW / Index.htm). The SPAW model predicts the hydraulic performance of LULC considering a one-dimensional water budget based on daily time intervals [28]. The model is commonly used to simulate major components in the water budget such as runoff, infiltration or evapotranspiration.

5. Average annual potential evapotranspiration as a fundamental component of the hydrologic budget including both soil and grass transpiration. As recommended by the InVEST User's Guide, evapotranspiration was determined with reference to scientific data [29] and subsequently compared with the Penman-Monteith method as described in Irrigation and Drainage Paper No. 56 published by the Food and Agriculture Organisation using data from the Climatic Research Unit [30]. 
6. Land use/land cover (LULC). The capacity of an ecosystem to provide services is closely related to LULC quality and biophysical conditions [31]. LULC is a key measure for linking human and natural systems for environmental management [32,33] and for spatial planning processes aimed at increasing sustainability. The LULC layer was created painstakingly, given the paucity of reliable, detailed data from different databases as defined by Arcidiacono et al. [21];

7. Watersheds and sub-watersheds, cartographically identified in the "Mapa das Bacias e Sub-bacias Hidrográficas do Município do Rio de Janeiro-2004" (www.data.rio).

8. Biophysical tables containing the nutrient loading and removal allocations (nitrogen and phosphorus) for each LULC class. Considering the lack of data for Rocinha area, nutrient data were derived according to the scientific documentation suggested by the InVEST User's Guide [29,30,34-36] (See Table A1). These data were also used to estimate nutrient retention.

\section{Results}

As stated previously, the model provides the upstream water yield maps as an intermediate output. The model expresses "the number of upstream pixels that must flow into a pixel before it is considered part of a stream" [37]. The quality of this output depends on the DEM as a raster layer in which each cell has a value corresponding to its elevation. The runoff does not consider whether if the water routes move via surface, subsurface or baseflows, it interacts with LULC and impervious surfaces. This intermediate output shows a key process that occurs when rain is not absorbed into the soil (for example when an impermeable surface reduces the area in which infiltration to groundwater can occur) and moves along gravitational lines flowing downhill in a runoff process. Water that has not been absorbed into the soil through the infiltration process is stored as groundwater and slowly discharged into streams through springs.

The upstream process must be considered in order to mitigate its potential negative consequences and existing critical situations, to stabilise soil (for example through planting or structural interventions), prevent disaster risk and increase resilience. Given Rocinha's geomorphological configuration, it is necessary to evaluate the stability of the terrain under various loading conditions (for example heavy rainfall) that could place buildings and residents at risk from landslides. The output of the model identifies areas subject to landslide risk where it is essential to implement a strategic recovery action and makes it possible to evaluate possible interventions to limit erosion, capture runoff to mitigate nutrient pollution and use available surface and subsurface water to create purification pools for urban gardening purposes. ES-based assessment gives technical robustness to environmental sustainability analyses designed to select actions that can be implemented in the favela. The intermediate output concerning nutrient retention is used to establish the resilience-oriented strategies of the project more practically.

Areas potentially affected by flooding and landslides as a result of heavy rainfall were identified using the intermediate output of the nutrient retention model concerning upstream water yield. Six "catchment areas" were determined based on the upstream water yield model as a basin-shaped area of land, bounded by natural features (hills or mountains) from which surface and subsurface water flow into streams, rivers and wetlands (Figure 2).

The catchment areas were selected considering the intensity of upstream water phenomena in order to propose nature-based solutions capable of mitigating flood risk.

The amount of upstream water was estimated in order to consider the types of strategies to implement depending on the risk posed by water flows. The InVEST output model estimates upstream water (in millimetres) for each pixel of the raster file. Each pixel represents an area of 6.4 by $6.4 \mathrm{~m}$ or $40.96 \mathrm{~m}^{2}$. The raster file makes it possible to estimate the water stored in the area represented by each pixel, as explained in Figure 2b.

Assuming that 1 millilitre of water corresponds to $1 \mathrm{~L} / \mathrm{m}^{2}$, the following formula was used:

$$
\text { Upstream }=\text { Quantity of upstream water } / \text { area }
$$


Based on the estimates of water stored in each catchment area and vulnerability to disaster risk (Table 1), two types of resilience-building actions were selected as feasible and concretely implementable given the local and socio-economic conditions of the favela: green mitigation measures and building replacement. The feasibility of these actions was also validated by the local knowledge of stakeholders previously involved in the data collection.

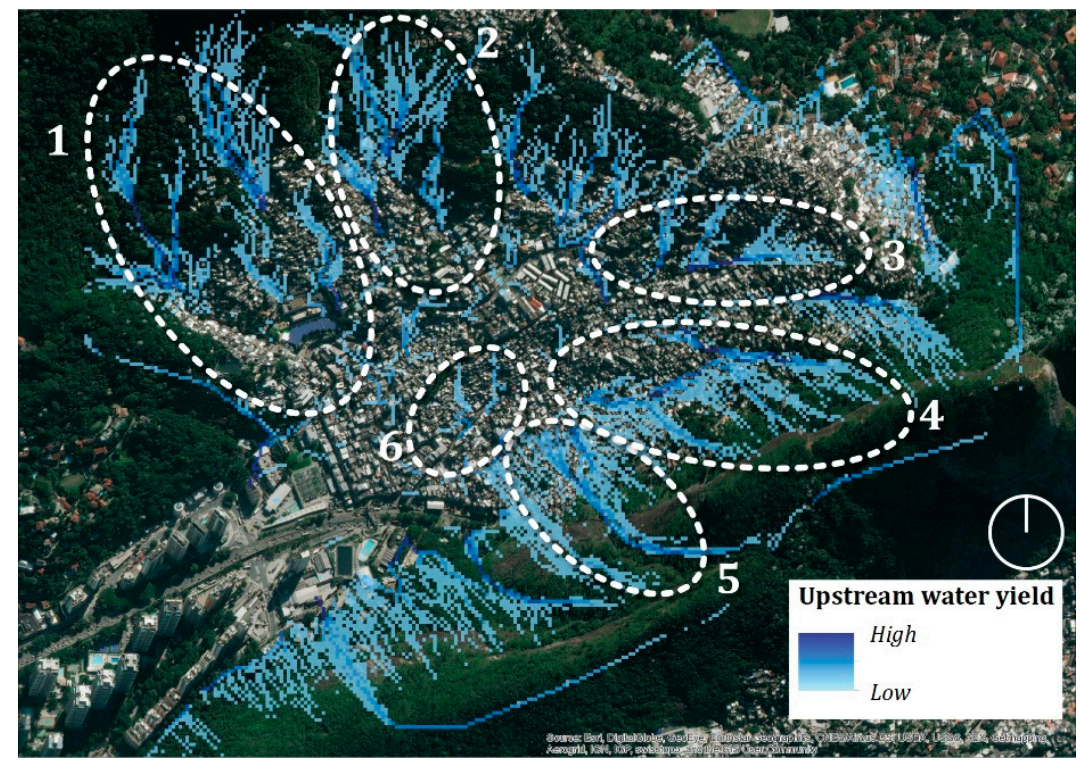

(a)

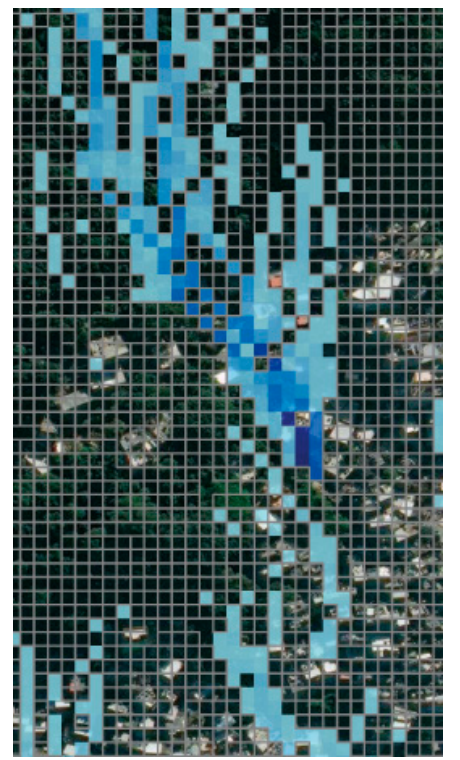

(b)

Figure 2. (a) The six upstream water catchment areas; (b) Output for upstream water output at pixel-level detail.

Table 1. Quantity of water stored in each upstream water area.

\begin{tabular}{cc}
\hline Upstream Water in the Catchment Area & Quantity of Water Stored (Litres/Catchment Area) \\
\hline 1 & $241,847.91$ \\
2 & $155,040.26$ \\
3 & $141,105.44$ \\
4 & $293,899.35$ \\
5 & $22,260.31$ \\
6 & $204,123.52$ \\
\hline
\end{tabular}

Green mitigation measures are a nature-based solution that complement or offer an alternative to conventional engineering measures. They seek to exploit complex natural features and processes to achieve local resilience, improve well-being and foster socially inclusive green growth. Green mitigation focuses on existing partially or wholly impermeable built-up areas, for example through the installation of green roofs, cool roofs and water storage systems to limit the impact of severe storms, flooding and landslides and to mitigate the heat island effect. Specifically, potential green mitigation actions include:

- Green roofs. These are roofs covered with vegetation placed over waterproofing material with drainage and irrigation systems. They can provide a range of ecosystem services, hence contributing to human well-being. Green roofs can improve rainwater drainage, thereby mitigating erosion, and also help purify groundwater by acting as a filter. They are a source of biodiversity, offering habitats for wildlife such as butterflies, bees and worms, while acting as a "stepping stone" for birds. They also absorb ultraviolet rays and improve building insulation by cooling buildings during the summer, while during the rainy season the vegetation coverage 
absorbs water, taking the pressure off building drainage systems. Finally, green roofs help trap atmospheric pollutants by absorbing carbon dioxide and sulphur dioxide. The Green My Favela project (http:/ / www.greenmyfavela.org/) was set up to reclaim degraded land and create more productive green spaces inside favelas and involved several favelas across Brazil, including Rocinha [38].

This nature-based solution is applicable in all of the catchment areas to buildings over 7-8 floors (21-24 m) in height, which is considered to be the maximum possible in Rocinha considering building standards. The adoption of this NBS in other buildings is strongly discouraged as residents are in the habit of extending their houses by building new storeys, one on top of the other, and terraces at the top of buildings are considered private spaces in the absence of alternatives elsewhere. An analysis was conducted to identify buildings suitable for green roof coverage using remote data from Google Maps (street view) and inspections in loco. The results of this building analysis are shown in Figure 3.

- Green permeable paving consists of pre-cast blocks made of concrete or hard plastic with voids created by styrene void formers. Such modular systems reduce sub-base depths, eliminate kerb edges, can withstand gross vehicle weights of over 40 tonnes and optimise drainage capacity, and have already been applied in different favelas (e.g., the Guarapiranga basin, Brazil) where impermeable surfaces (asphalt) have been replaced with concrete blocks. The blocks have also been used in rural areas to create paths in unpaved areas. Permeable paving is connected with the strategy of demolishing buildings.

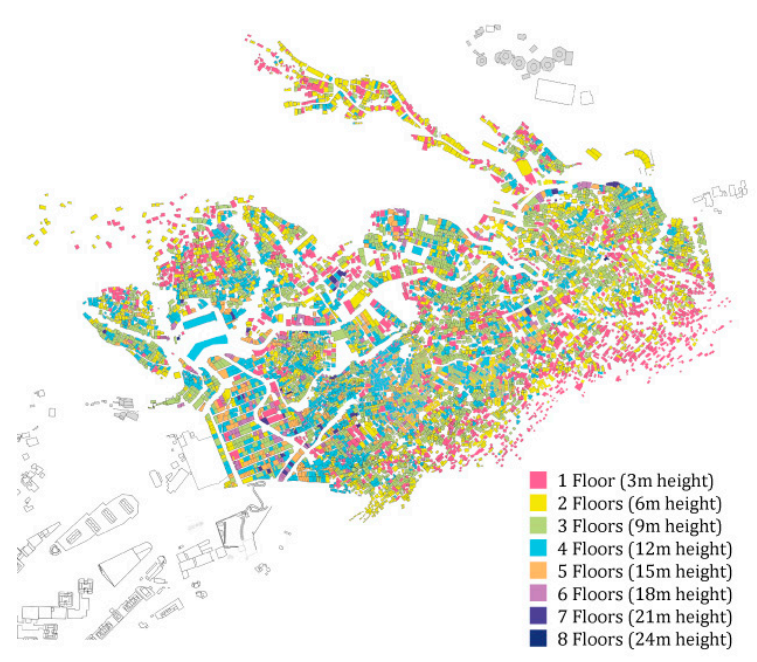

(a)

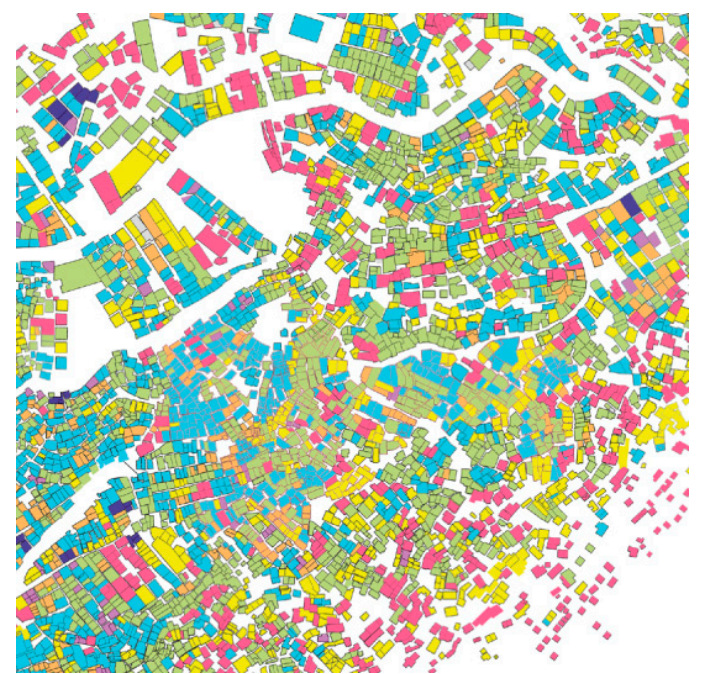

(b)

Figure 3. (a) building heights in Rocinha; (b) details of building heights.

In favelas, most buildings are non-engineered and consist of simple structures made of brick-filled reinforced concrete, casting doubts on the solidity of their foundations and on their capacity to withstand hazards caused by intense rainfall and landslides [1].

Specifically, if the strategy includes demolition, the original area must be desealed to create permeable green spaces (including permeable paving), with positive effects on the water cycle. If the strategy makes provision for new building or densification, then mitigation measures, such as green roofs, must be incorporated.

Building relocation frees up green space that can be used to host urban gardens and other kinds of urban agriculture, contributing to significant ecosystem services such as biodiversity conservation, food production and aesthetic value. Urban gardens permit vegetables, medicinal plants, spices, mushrooms, fruit trees, ornamental plants, and other productive plants to be cultivated in order to 
meet the needs of the local community. The use of different types of plant species also enhances the landscape and hence its aesthetic value.

Seven intervention areas were selected based on the upstream water output for the demolition of existing buildings and their relocation to a new area with a view to freeing up space for permeable surfaces (Figure 4).

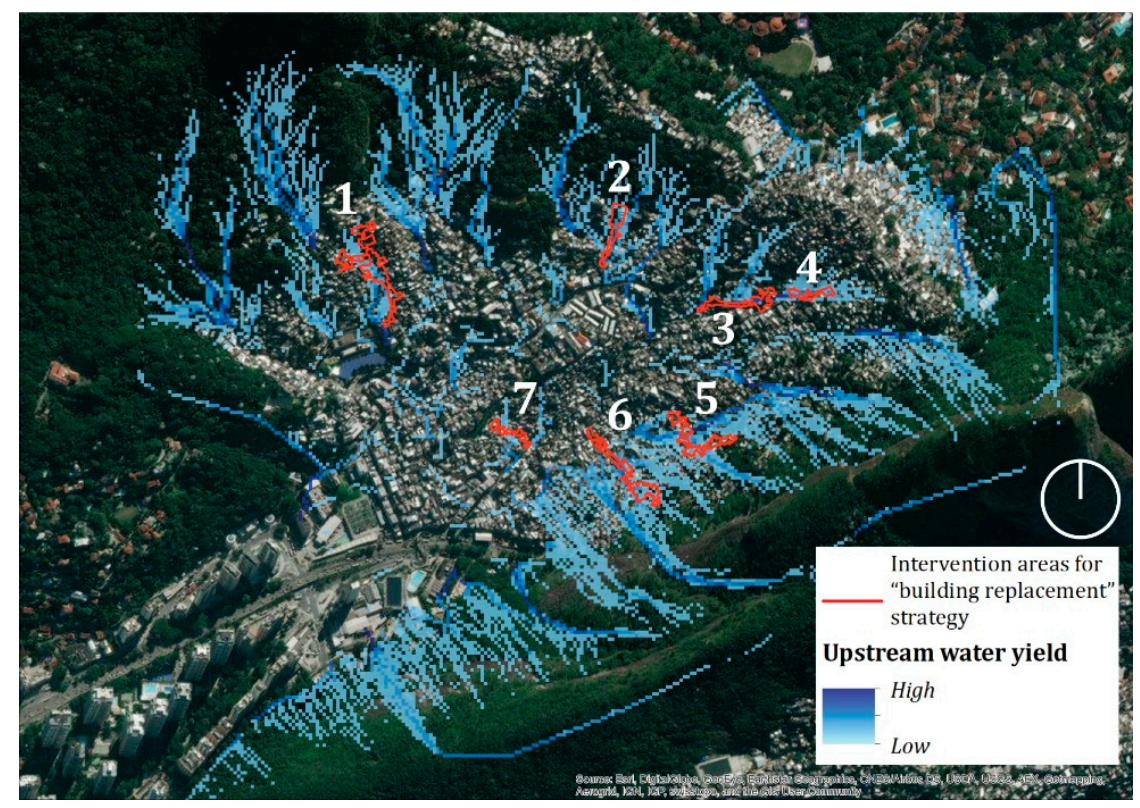

Figure 4. Intervention areas affected by the "building replacement" strategy.

A small number of buildings were selected in three areas of intervention according to the urgency and efficacy of the intervention and in conjunction with the local stakeholders involved in the research, which was essential for gaining the consensus of the local community and hence for the feasibility of the project (Figure 5).

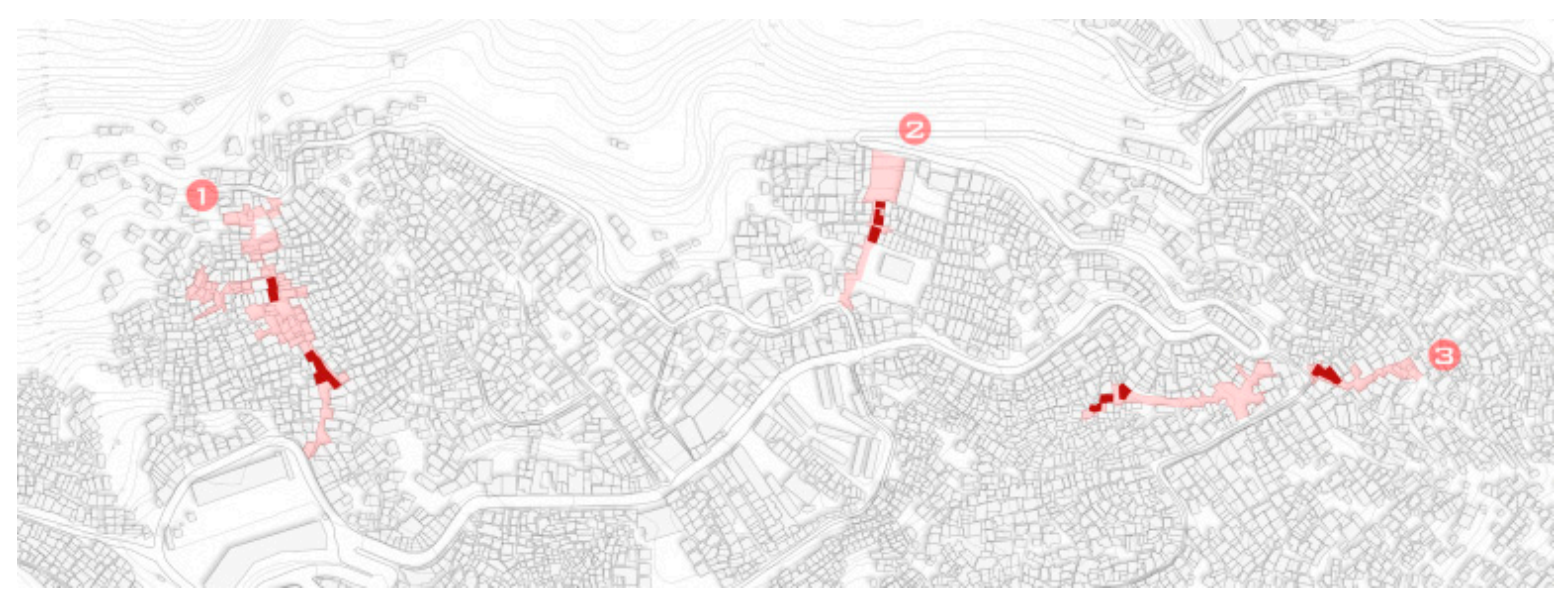

Figure 5. Selection of buildings (in dark red) to be relocated within the three intervention areas.

Moreover, structural interventions could be combined with some of the measures outlined above, such as the development of urban gardens based on terracing systems to retain soil and counter flooding, or the construction of water tanks along runoff streams on hillslopes to store rainwater and on impervious surfaces such as roofs, thus reducing runoff directly into streams. The water collected in 
these tanks could also be used to flush toilets, wash clothes, water gardens and wash cars, significantly reducing the demand for drinking water.

\section{Discussion}

The upstream water yield output was verified according to previous events of moderate flooding occurred in the catchment area 1 and 3 demonstrating the accuracy of the model and data used. The collection of input data is one of the most complex aspects and the main limitation of the InVEST software, which requires a large amount of data, which are often inaccurate or not readily available, meaning that several simplified assumptions need to be made with a margin of uncertainty. While the methodology and nature-based solutions proposed are replicable and feasible in various contexts, the parameters and values used for ES mapping are site-specific and hence demand precise adaptation and data collection.

The research shows the overcoming of the lack of data providing, on the one hand, important sources for mapping and assessment water regulation in Brazil and, on the other hand, the first knowledge base for flooding risk control in Rocinha.

The output identifies some critical situations that require strong interventions for limiting possible disaster risks. Upstream water yield map establishes urban priorities, specifically with regard to green mitigation strategies and building replacement. While green mitigation measures are location-independent within the area (essentially depending on building characteristics in the case of our research), building relocation strategies can be deployed in locations where specific hydrogeological risks can be contained or prevented.

Although the flood resilient strategies described in this paper are limited in number and relatively simple, they offer extremely effective and practicable strategies for mitigating flood risk.

The analysis conducted is a potential starting point for a monitoring programme as part of an ongoing process to evaluate the success of an action and its effects. The monitoring programme could also be used to verify the state of and trends in ES provision using predictive modelling or scenario-building approaches. InVEST software allows scenarios based on LULC changes and the possible extent of such changes to be modelled.

\section{Conclusions}

The research shows that in informal contexts such as favelas, which are often at risk from natural disasters such as landslides or flooding, it is possible to adopt resilience strategies derived from ES mapping and assessment. The methodology outlined assumes ES mapping to be key to establishing appropriate actions to foster system resilience.

The nature-based solutions and building relocation strategies be combined with solutions already implemented in South America, for example in the Guarapiranga basin (Brazil), for the peri-urban areas of the favelas, where a public recreation space was created including an urban garden structured on different levels and heights with a system of circular streams to prevent outside interference and intrusion (http:/ /www.temafavela.com.br/site/) [39]. Combining recreational ecosystem services with provisioning and regulating functions represents a first step in the development of local green infrastructure (GI), defined as "a strategically planned network of natural and semi-natural areas with other environmental features designed and managed to deliver a wide range of ecosystem services. It incorporates green spaces (or blue if aquatic ecosystems are concerned) and other physical features in terrestrial (including coastal) and marine areas. GI is a tool for providing ecological, economic and social benefits through natural solutions. It helps avoid relying on 'grey infrastructure' that is expensive to build when nature can provide cheaper, more durable alternatives" [40]. In the case of Rocinha, GI could be a framework for collective (and not only nature-based) actions to improve overall human well-being and quality of life in urban environments. It can involve a range of policy areas (such as climate action, disaster risk management, water policy, health policy, agricultural and forestry 
policy) and hence become a primary strategy for cross-sector policy, avoiding the over-separation of roles and competencies which often hinders concrete implementation of prevention strategies.

Moreover, nature-based solutions to socio-economic and environmental challenges are increasingly the focus of technical assessments, as they often provide cost-effective solutions. One possible future research scenario may involve physically designing GI based on an evaluation of the impact of the project in terms of ecosystem services from an environmental and socio-economic perspective and the costs of implementation.

Author Contributions: All authors equally contributed to the article.

Funding: The research was funded by the Politecnico di Milano through its 2016 "Polisocial Award" programme.

Acknowledgments: The authors would like to thank the Politecnico di Milano research group, the Federal University of Rio de Janeiro and "Il Sorriso dei Miei Bimbi", a non-profit organisation engaged with the community of Rocinha, for their activity in the project called "PolimiporRocinha". The authors are grateful to the research group of the Department of Architecture Built Environment and Construction Engineering (DABC), Politecnico di Milano, for the contribution to the elaboration of Figures 3 and 5. The paper summarises the initial outcomes of the project, specifically the analysis conducted by the Department of Architecture and Urban Studies of the Politecnico di Milano, one of the departments involved in the project.

Conflicts of Interest: The authors declare no conflict of interest. The funders had no role in the design of the study; in the collection, analyses, or interpretation of data; in the writing of the manuscript, or in the decision to publish the results.

\section{Appendix A}

Table A1. Table of input data associated with LULC classes *.

\begin{tabular}{|c|c|c|c|c|c|c|}
\hline LULC_code & Root_depth & Kc & load_n & load_p & eff_n & eff_p \\
\hline 1111 & 1 & 0.156122052 & 0 & 0 & 0 & 0 \\
\hline 111 & 1 & 0.224183527 & 0 & 0 & 0 & 0 \\
\hline 112 & 1 & 0.287409281 & 0 & 0 & 0 & 0 \\
\hline 121 & 1 & 0.108610855 & 0 & 0 & 0 & 0 \\
\hline 122 & 1 & 0.261009662 & 0 & 0 & 0 & 0 \\
\hline 123 & 1 & 0.108610855 & 0 & 0 & 0 & 0 \\
\hline 124 & 1 & 0.108610855 & 0 & 0 & 0 & 0 \\
\hline 131 & 1 & 0.100072785 & 0 & 0 & 0 & 0 \\
\hline 141 & 550 & 0.522455436 & 0 & 0 & 0.6 & 0.6 \\
\hline 142 & 1 & 0.537704119 & 0 & 0 & 0 & 0 \\
\hline 211 & 675 & 0.483 & 210 & 80 & 0.4 & 0.4 \\
\hline 212 & 800 & 0.616 & 275 & 100 & 0.4 & 0.4 \\
\hline 221 & 1500 & 0.4 & 76 & 44 & 0.4 & 0.4 \\
\hline 222 & 1200 & 0.75 & 85 & 55 & 0.4 & 0.4 \\
\hline 231 & 550 & 0.72 & 0 & 0 & 0.6 & 0.6 \\
\hline 241 & 800 & 0.72 & 30 & 90 & 0.4 & 0.4 \\
\hline 2440 & 800 & 0.72 & 30 & 90 & 0.4 & 0.4 \\
\hline 311 & 1500 & 0.7 & 0 & 0 & 0.8 & 0.8 \\
\hline 321 & 550 & 0.72 & 0 & 0 & 0.6 & 0.6 \\
\hline 322 & 550 & 0.72 & 0 & 0 & 0.6 & 0.6 \\
\hline 324 & 550 & 0.72 & 0 & 0 & 0.6 & 0.6 \\
\hline 330 & 1 & 0 & 0 & 0 & 0.6 & 0.6 \\
\hline 331 & 1 & 0 & 0 & 0 & 0.6 & 0.6 \\
\hline 332 & 1 & 0 & 0 & 0 & 0.6 & 0.6 \\
\hline 410 & 0 & 0 & 0 & 0 & 0 & 0 \\
\hline 411 & 0 & 0 & 0 & 0 & 0 & 0 \\
\hline 511 & 0 & 0 & 0 & 0 & 0 & 0 \\
\hline 512 & 0 & 0 & 0 & 0 & 0 & 0 \\
\hline 523 & 0 & 0 & 0 & 0 & 0 & 0 \\
\hline
\end{tabular}

* LULC_code is based on the Corine Land Cover legend (Available online: http:/ / uls.eionet.europa.eu/CLC2006/ CLC_Legeng.pdf). Root_depth is the maximum root depth. $\mathrm{Kc}_{\mathrm{c}}$ is the Evapotranspiration coefficient. load_n/load_p: The nutrient loading for each land use. eff_n/eff_p. The vegetation filtering value per pixel size for each LULC class. 


\section{References}

1. Lange, W.; Sandholz, S.; Nehren, U. Strengthening Urban Resilience through Nature: The Potential of Ecosystem-Based Measures for Reduction of Landslide Risk in Rio de Janeiro; Working Paper WP18WL1; Lincoln Institute of Land Policy: Cambridge, MA, USA, 2018. [CrossRef]

2. de Assis Dias, M.C.; Saito, S.M.; dos Santos Alvalá, R.C.; Stenner, C.; Pinho, G.; Nobre, C.A.; de Souza Fonseca, M.R.; Santos, C.; Amadeu, P.; Silva, D.; et al. Estimation of exposed population to landslides and floods risk areas in Brazil, on an intra-urban scale. Int. J. Disaster Risk Reduct. 2018, 31, 449-459. [CrossRef]

3. Istituto Moreira Salles Memoria Rocinha. Available online: http://memoriarocinha.com.br/en/linha-dotempo/ (accessed on 20 June 2018).

4. Jones, J.A.A. Water Sustainability: A Global Perspective; Hodder Education; Taylor \& Francis Ltd.: London, UK, 2010; ISBN 9781444104882.

5. de Groot, R.; Wilson, M.A.; Boumans, R.M.J. A typology for the classification, description and valuation of ecosystem functions, goods and services. Ecol. Econ. 2002, 41, 393-408. [CrossRef]

6. Alcamo, J.; Hassan, R. Ecosystems and Human Well-Being. A Framework for Assessment; Island Press: Washington, DC, USA, 2003; Volume 5, ISBN 1559634022.

7. TEEB. The Economics of Ecosystems and Biodiversity for National and International Policy Makers—Summary: Responding to the Value of Nature; TEEB: Geneva, Switzerland, 2009.

8. McPhearson, T.; Andersson, E.; Elmqvist, T.; Frantzeskaki, N. Resilience of and through urban ecosystem services. Ecosyst. Serv. 2015, 12. [CrossRef]

9. Frantzeskaki, N.; Tilie, N. The dynamics of Urban ecosystem governance in Rotterdam, the Netherlands. Ambio 2014, 43, 542-555. [CrossRef] [PubMed]

10. Andersson, E.; Tengö, M.; McPhearson, T.; Kremer, P. Cultural ecosystem services as a gateway for improving urban sustainability. Ecosyst. Serv. 2015, 12, 165-168. [CrossRef]

11. Nehren, U.; Sudmeier-Rieux, K.; Sandholz, S.; Estrella, M.; Lomarda, M.; Guillén, T. The Ecosystem-Based Disaster Risk Reduction: Case Study and Exercise Source Book; Partnership for Environment and Disaster Risk Reduction and Center for Natural Resources and Development: Geneve, Switzerland; Cologne, Germany, 2014; ISBN 978-3-00-045844-6.

12. European Commission. A Framework Strategy for a Resilient Energy Union with a Forward-Looking Climate Change Policy; European Commission: Brussels, Belgium, 2015; pp. 1-21. [CrossRef]

13. Potschin, M.; Kretsch, C.; Haines-Young, R.; Furman, E.; Berry, P.; Baró, F. Nature-based solutions. In OpenNESS Ecosystem Service Reference Book; Potschin, M., Jax, K., Eds.; EC FP7 Grant Agreement No. 308428; 2015; Available online: www.openness-project.eu/library/reference-book (accessed on 18 December 2018).

14. European Commission. Towards an EU Research and Innovation Policy Agenda for Nature-Based Solutions $\mathcal{E}$ Re-Naturing Cities; European Commission: Brussels, Belgium, 2015; ISBN 978-92-79-46051-7.

15. The World Bank. Implementing Nature-Based Flood Protection: Principles and Implementation Guidance; The World Bank: Washington, DC, USA, 2017; pp. 7-31.

16. Grizzetti, B.; Lanzanova, D.; Liquete, C.; Reynaud, A.; Cardoso, A.C. Assessing water ecosystem services for water resource management. Environ. Sci. Policy 2016, 61, 194-203. [CrossRef]

17. IBGE_-Instituto Brasileiro de Geografi a e Estatística Mostra a Nova Dinâmica da Rede Urbana Brasileira. Available online: http: / / www.ibge.gov.br (accessed on 7 June 2017).

18. Rekow, L. Fighting insecurity: Experiments in urban agriculture in the favelas of Rio de Janeiro. Field Actions Sci. Rep. 2015, 8, 1-8.

19. Bosselmann, P. Urban Transformation. Understanding City form and Design; Island Press: Washington, DC, USA, 2009.

20. Carmona, M.; Tiesdell, S.; Heath, T.; Oc, T. Public Plance Urban Space; Architectural Press Elsevier: Oxford, UK, 2003.

21. Arcidiacono, A.; Causone, F.; Grosso, M.; Masera, G.; Tadi, M.; Zadeh, H.M. Environmental Performance and Social Inclusion: A Project for the Rocinha Favela in Rio de Janeiro. Energy Procedia 2017, 134, 356-365. [CrossRef] 
22. Gómez-Baggethun, E.; Kelemen, E.; Martín-López, B.; Palomo, I.; Montes, C. Scale Misfit in Ecosystem Service Governance as a Source of Environmental Conflict. Soc. Nat. Resour. 2013, 26, 1202-1216. [CrossRef]

23. UN Habitat. Enhancing Urban Safety: Global Report of Human Settlements; United Nations Human Settlement Program: Nairobi, Kenya, 2007.

24. Salata, S.; Garnero, G.; Barbieri, C.; Giaimo, C. The Integration of Ecosystem Services in Planning: An Evaluation of the Nutrient Retention Model Using InVEST Software. Land 2017, 6, 48. [CrossRef]

25. Scott, K.; Pain, C. Regolith Science; Springer: Dordrecht, The Netherlands, 2009; ISBN 978-1-4020-8859-9.

26. Fitzpatrick, R.; McKenzie, N.; Maschmedt, D. Soil morphological indicators and their importance to soil fertility. In Soil Analysis: An Interpretation Manual; CSIRO Publishing: Melbourne, Australia, 1999; pp. 55-69.

27. Naidoo, G.; Mundree, S.G. Oecologia. Oecologia 1993, 93, 360-366. [CrossRef] [PubMed]

28. Saxton, K.E. Soil water hydrology: Simulation for water balance computations. New Approaches Water Balanc. Comput. 1983, 47-60. [CrossRef]

29. Droogers, P.; Allen, R.G. Estimating reference evapotranspiration under. Irrig. Drain. Syst. 2002, 16, 33-45. [CrossRef]

30. Allen, R.G.; Pereira, L.S.; Raes, D.; Smith, M. Crop Evapotranspiration. Irrig. Drain. 1998, 300, 300. [CrossRef]

31. Burkhard, B.; Kroll, F.; Nedkov, S.; Müller, F. Mapping ecosystem service supply, demand and budgets. Ecol. Indic. 2012, 21, 17-29. [CrossRef]

32. Balmford, A.; Beresford, J.; Green, J.; Naidoo, R.; Walpole, M.; Manica, A. A global perspective on trends in nature-based tourism. PLoS Biol. 2009, 7, 1-6. [CrossRef] [PubMed]

33. Arcidiacono, A.; Ronchi, S.; Salata, S. Ecosystem Services assessment using InVEST as a tool to support decision making process: Critical issues and opportunities. In Computational Science and Its Applications -ICCSA 2015; Springer: Cham, Switzerland, 2015; pp. 35-49. ISBN 978-3-319-21406-1.

34. Reckhow, K.H.; Beaulac, M.N.; Simpson, J.T. Modeling phosphorus loading response under uncertain. A manual and compilation of export coefficients. Water Resour. Res. 1980, 30, 214.

35. Haycock, N.; Burt, T.; Goulding, K.; Pinay, G. Buffer Zones: Their Processes and Potential in Water Protection; Haycock Associated Limited: Otley, UK, 1996; ISBN 0953005100.

36. White, M.J.; Arnold, J.G. Development of a simplistic vegetative filter strip model for sediment and nutrient retention at the field scale. Hydrol. Process. 2009, 23, 1602-1616. [CrossRef]

37. Tallis, H.T.; Ricketts, T.; Guerry, A.D.; Wood, S.A.; Sharp, R.; Nelson, E.; Ennaanay, D.; Wolny, S.; Olwero, N.; Vigerstol, K.; et al. VEST 2.0 Beta User's Guide. 2011. Available online: https://unstats.un.org/unsd/ envaccounting/seeaRev/meeting2013/EG13-BG-4.pdf (accessed on 18 December 2018).

38. Rekow, L. Green My Favela: An Act of Defiance. Int. J. Educ. Art 2012, 8, 305-319. [CrossRef]

39. Farah Nagati, L.; De Assis Lefèvre, J.E. Urbanização de Favela na Bacia da Guarapiranga. Available online: http:/ / www.temafavela.com.br/site/tfg-lilian/ (accessed on 9 May 2017).

40. European Commission. Building a Green Infrastructure for Europe; Publications Office of the European Union: Luxembourg, 2013; ISBN 9789279334283.

(C) 2018 by the authors. Licensee MDPI, Basel, Switzerland. This article is an open access article distributed under the terms and conditions of the Creative Commons Attribution (CC BY) license (http://creativecommons.org/licenses/by/4.0/). 